\title{
DYNAMICS OF DEFIANT GENDERED SUBALTERN IN MAHASWETA DEVI'S 'DRAUPADI'
}

\author{
JANE CICILIA BARLA ${ }^{1} \& D R$. SUPRIYA ${ }^{2}$ \\ ${ }^{I}$ Research Scholar, Department of English, Ranchi University, Ranchi \\ ${ }^{2}$ Associate Professor, PG Department of English, Ranchi women's college (An Autonomous Constituent Unit of Ranchi \\ University)
}

\begin{abstract}
Mahasweta Devi, an ardent activist and creative writer with a purpose, offers an insight into the problems of oppressed marginalized classes through her numerous imaginative expressions. In order to break the historical silencing of the voices of protest against the atrocities of the mainstream, Devi situates her story Draupadi in the backdrop of the Naxalite movement related Operation Bakuli (1971) that sought to kill the tribal 'rebels' with a subtle allusion to the ancient Hindu epic of Mahabharata, engaging with the complex politics of justice, class, gender and individual identity in contemporary India. The present research paper is an attempt to critically appreciate the story about the protagonist Dopdi Mehjen who dares to be what Draupadi of patriarchal and authoritative sacred text of the epic Mahabharata could not be. She reconditions the physicality of her body from powerlessness into powerful resistance. Instead of romanticized depiction of the double marginalized female tribal, Devi realistically presents the gendered subaltern subject who exists at the periphery of society and dares to go against the existing patriarchal structures through simple language and complex emotions. With Dopdi at the centre, the story explores the ruthlessly exploitative and anti-people politics around the category of the 'subaltern' by depicting the dynamics of injustice - social, physical and mental.

KEYWORDS: Injustices, Marginalized, Silenced, Defiant, Gendered Subaltern
\end{abstract}

Received: Jan 09, 2021; Accepted: Jan 29, 2021; Published: Feb 09, 2021; Paper Id.: IJELJUN20211

\section{INTRODUCTION}

Mahasweta Devi is a renowned contemporary Bengali writer and a social activist known for her works addressing to forms of oppression, sexual harassment, exploitation of down trodden and domestic violence. Ghatak, Devi's cosocial researcher and activist, opines that as "a seasoned realist with a wide experience of ground level activism amongst the most vulnerable, Devi recognizes and depicts the system as ruthlessly exploitative and anti-people in her fiction" (Ghatak: xv).She believed that a creative writer should have a social conscience. In an interview she emphasises, "I have a duty towards society ... I ask myself this question a thousand times: have I done what I could have done?'[Devi: Imaginary Maps, xi) In the words of Arya in his book Tribal Activism: Voices of Protest "Devi's activism and art are two sides of the same coin - her philanthropy" (16) and this fact undoubtedly gives an authenticity ring to her creative work.In her introduction to Agnigarbha she dismisses any political agenda of her writings and says that "[her] writings are principally aimed at creation of sensitivity towards and concern for the exploited and oppressed man" (Arya: 10). 
The harsh and often shocking content of her stories like The Hunt, Breast-Giver, Draupadi, Douloti, the Bountiful, often attract negative criticism as nothing more than a literary stunt to shock the urban middle-class sensitivity. But the charge itself is an acceptance of the ignorance of the grim realities of rural/tribal life among her readers. Devi has reiterated again and again in all her interviews that the characters in her fictions are not intended to be imaginary, instead "... they or their prototypes exist outside the story.... Real details of real poverty learnt at firsthand. Real characters with real life histories"(katyal: 25).

In Draupadi Mahasweta Devi has given a graphic representation of the difficulties and problems of the lower caste community and a hint of hope against hopelessness. In preface to the novel Bashai Tudu she has opined how during 1959 the Naxal movement took a violent turn and all the peasants evicted the zamindars from their lands. This revolt was not limited to the place of its origin like the Naxalbari village of West Bengal, it spread in other states of India like Andhra Pradesh, Kerala, Tamil Nadu, Bihar and Orissa.This movement is now branded as an 'extreme left deviation, the manifestation of the frustration of a group of idealistic and over-enthusiastic young men' (Bashai Tudu, xx). Most of her narratives are piqued with issues of gender oppression enmeshed within its class and caste dichotomies. Kanika Biswas in her essay on Mahasweta's representation of subaltern has offered two major categories to define Devi's activist writing(a) representing and (b) challenging the prevalent socio-political structure.( Bhowmik 2003: 155-6). The representation and challenge to the socio political structure is expressed in terms of resistant movements against the prolonged injustices and violence in the Indian tribal history. However, these revolts and movements against injustices have always been suppressed by the unleashing forces of power in the mainstream. Devi's creative writings have emerged as effective tools to help the suppressed people revive their senseof pride and identity as individuals. In one of the interviews, Mahasweta Devi tells what made her write about tribal history:

Once a tribal girl asked me 'When we go to school, we read about Mahatma Ghandhi. Did we have no heroes? Did we always suffer like this?' That is why I started writing about the tribal movements and tribal heroes. (Devi, Imaginary Maps iii)

Even in contemporary India the thirst for equal rights and individual identity for Dalits and Tribals remains largely unquenched.Vishesh Gupta's article, Varga Sangharsha Ki Vichardhara ("The Ideology of Class Struggle”) probes deep into roots of the Maoist and Naxal movements ${ }^{1}$. Commenting on the chasm between the Naxals of 1970 s and those of today, he points out that the ideology of early naxalism was based on apparent class conflict, inequality and injustice. It was vigorously promoted and campaigned in deprived rural regions as a means of proper redistribution of land.The landless farmers and labourers saw it as a path to liberation from oppression and exploitation, even though a violent one. Thegovernment havingfailed miserably to provide basic amenities of life to these marginalized tribals and dalits living in remote areas resorted to suppress the insurgent Naxal movement, but fascination for it nonetheless grew alarmingly. In the last two decades, poverty, unemployment, increase in the number of landless farmers, injustice and inequality in land distribution and rude intervention in the lives of local indigenous tribals have multiplied and intensified their alienation.

Though there have been constant revolts and tribal people have actively participated in the movements but voices of revolt remain muffled. The short story Draupadi has graphically brought in light how both before and after colonial periods the tribals have suffered owing to zamindari system which controlled and deprived them of their basic necessities of survival like water, land and food which was further compounded by the insensitive and antagonistic intervention by the authorities. Devi situates her story against the backdrop of the tribal uprising against wealthy landlords which brought upon 
the fury of the government culminating in Operation Bakuli (1971) that sought to kill the so-called tribal rebels and the ancient Hindu epic of Mahabharata, engaging with the complex politics of gendered subaltern identity in the patriarchal class conscious Indian society. Devi's Dopadi dares to be what Draupadi of patriarchal and authoritative sacred text of the epic Mahabharata could not be. Mahasweta Devi has always been a constant supporter of underprivileged and through her characters she has voiced the oppression and resistance which is igniting every day. Through most of her protagonists like Draupadi, Giri and Dhowli, she tells the readers not to suffer from exploitation or resort to any activity of vengeance but rather be autonomous voice of resistance and protest. In the short story Giribala, Devi gives another instance of gender violence and brutality where the character named Giri, a fourteen years old girl, is married to an abusive husband named Aulchand and is persistently subordinated in patriarchal dictum. She gives birth to five daughters who later become the victim of sexual commodification and married off at an early age of twelve by their father for rupees four hundred.

Set in the tribal belt of West Bengal the story has a backdrop of the Naxalite revolt; it depicts a major peasant rebellion which began late in 1960's in the naxalbari region of West Bengal. This rebellion was inevitable as it started as a revolutionary movement in favour of agrarian reform in response to generations of feudal exploitation by landowners which was pervasive before independence in the form of low wages, bonded labour and sexual exploitation of tribal women. The protagonist Draupadi or Dopdi Mehjen belongs to a Santhaltribe. Being a tribal by birth madeher evenmore vulnerable under the shadows of atrocious government officials. She is twenty- seven years old from Bakuli district in West Bengal who,along with her husband Dulna,is among the tribal revolutionaries involved in guerrilla warfare against the landlords. The couple have been hiding away from Indian army engaged in a search operation because of their involvement in the killing of the landlord named Surja Sahu and for capturing wells and tubewells of upper class.

The narrative opens with the police encounter of Dopdi's husband Dulna, the main suspect in the murder of Surja. The reiteration of the word 'kountered' (encountered)in the story shows how illegal killing of naïve tribals like Dulna has been legalized by the government by giving it a formal name for brutal suppression of voices of protest. Despite facing the atrocities of the landlords and government the people of Bakuli remain silenced as they are mortally afraid of repressive 'kounter' by the government agencies. The wretched and marginalized situation of the tribals has been depicted with brutal accuracy which exposes the savage mechanics of exploitation and oppression by the mainstream through varied means. With the help of lucid flashback narration, Devihas brought in account the main reasons behind the killing of the landlord. The story begins with the precarious life-style of people like Dulna and Draupadi who are totally dependent on the mercy of 'jotedars' and landlords. Thecontinuous deprivation of basic necessities of life as water and food instigated the conversion of suppressed rage into aggression which eventually resulted into the murder of Surja Sahu. The incessant exploitation and suppression of their community made them take this drastic step against the law which seemed to serve only the powerful. Surja Sahu's comments just before his death confirms the limited power of law against the privileged.

“Get out of here I don't accept Your Panchayat nonsense. Increase cultivation with water. You want half the paddy for share cropping. Everyone is happy with free paddy. Then give me paddy at home, give me money. I have learned by lesson trying to do you good.

What good did you do?

Have I not given water to the village?

You've given it to your kin Bhagunal. 
Don't you get water?

No, the untouchables don't get water.

The quarrel began there. In the drought, human patience catches fire easily."(Draupadi: 184)

Though the basic equation between the villagers and Surja Sahu is that of service giver and provider but the dialogues of Surja suggest his demeanour to be terribly self-centred. The tone shows the adamant and commanding nature of Surja which represents the tyranny of power which is beyond legal provisions. Surja Sahu, the landowner declares nonchalantly to the demands of the villagers, "Get out of here I don't accept Your Panchayat nonsense".

This kind of situation becomes an inevitable breeding ground of all kinds of nefarious activities for the victims of the circumstances. In the drought hit village where the downtrodden are not allowed access to water, Dopdi and her husband, Dhulna have been murdering wealthy landlords and usurp their wells, which is the primary source of water for the village. The metaphorical expression - "In the drought, human patience catches fire easily" - very effectively conveys the dismayed anger of the deprived. The exploitative action of Surja Sahu is challenged and finally taken to a violent conclusion by Dulna Majhi who kills Surja as well as his son in an outrage. Legally, the act of killing is an offense, a crime against humanity, but the circumstances which led to the killing of Surja also demand socio-legal attention in the perspective of constitutional promise of equality before law for its citizens without any discrimination. Unfortunately, even the Self-governing body at village level is inefficient in properly executing the legal rights of the people leading to glaring disparity in allocation of resources. According to the likes of Mahasweta Devi's Surja Sahu, the justice system of panchayatis a nonsensical thing. The anti-humanitarian/inhuman social stratification has been hit by the writer in very plain and direct language of Rana, “untouchables don't get water”. The statement is a grim reminder that even in modern India the atrocities against the subalterns are real in spite of the political promises of rural development and equal opportunities for the people existing at the margins.

The debt-trapped Dulna's helplessness gives an insight into the atrocious nature of the system. He says in rage, "I'll have the first blow, brothers. My great-grandfather took a bit of paddy from him, and I still give him free labour to repay that debt" (Draupadi: 184). The brutal power of the remnants of the zamindari system still exists in our villages which thrives on deceit and exploitation of the uneducated and naïve villagers. Of course there can be no justification for such a violent redressal but such an extreme step is a warning that it is imperative for the civilized society to ensure that the rising consciousness of the tribals or any other suppressed community in search of justice should not be allowed to degenerate into violent revenge and instigate them to take law into their own hands. In Draupadi the depiction of rebellion against the landlords and its aftermath is not a romantic wish to cleanse the system by adopting whatever means, but to lend a voice to the wronged, frustrated and helpless subalterns, here, the poor tribal villagers, who are becoming conscious of their identity and are asking for justice and a respectable position in society. The plot of the story illustrates that how patience of the tribals for justice has been tested repeatedly and the infinite delay and a biased mainstream support for the exploiters have worsened the condition of the marginalized driving them into the traps of a decadent 'naxalism' of selfinterest groups. The percolating message of the governmental response is reduced to the effect that the Special Forces, hand in glove with the upper caste landlords, are after the revolutionaries with a vengeance to suppress the cry of genuine concerns of the deprived. 
The intense story makes the reader conscious of the bitter truth that even after independence the atrocities of upper class have taken its stance despite the law for equality and justice. It is rightly marked by French realist novelist Honore de Balzac, "Laws are spider webs through which the big flies pass and the little ones get caught.”During the intense combing operation to control and suppress tribal insurgency the defenceless Dulna is hunted down and shot to death when he was quenching his thirst near a river. The hunting continues for his wife, Dopadi, who keeps changing her hideouts very frequently, her only means of survival. The police have laid traps at every fall and river for the rebel tribal woman, showing qualities quite different from the conventional image of a mainstream woman. Eventuallyher movements become too restricted and while the likes of Mushai Tudu's wife provide her 'cooked rice' to carry with her, other rebels like Shomai and Budhna succumb to greed and betray her. Ultimately hunger, thirst and fatigue betray her inner strength and zeal. The helpless Dopadi gives up, "Tell me, how many times can I run away? What will they do if they catch me? They will kounter me. Let them." Obviously, the poor woman could not even imagine that a far worse situation awaits her for being a female.

Finally, Draupadi is apprehended and brought in front of Senanayak, the army commandant, the officer in charge of the hunting operation. The choice of words used to describe him is very remarkable. He is "a specialist in combat and extreme left Politics", who believes in the dictum from the Army Handbook to which he always refers, "In order to destroy the enemy become one". No wonder he is inimical towards his own his fellow citizens. Ironically, the perpetrator is the agency of justice who orders the atrocious act of sexual torture to Dopadi. While she is under custody Senanayak utters a horrific single command to his men: "Make her. Do the needful". (Draupadi: 188) The action taken by Senanayak in pursuit of justice is utterly inhuman and unspeakable even for the officer himself. Dopdi bears the torture as she is gang raped with the ringing voice of another man Arijit urging her to save her comrades and not herself. Indeed, Draupadi is an imaginative transcription of a universal fact in its portrayal of woman as the most brutalized victim of any internal or crossborder conflict, the woman's body being the primary targets of attack by men. Ironically, the same officers who got her raped, insist that she covers up once she is 'done with'. Obdurately, Dopdi tears off her clothes and walks towards officer Senanayak, “...naked. Thigh and pubic hair matted with dry blood. Two breasts. Two wounds”. Senanayak is dazed by her defiance as she confronts him "with her hand on her hip" as "the object of [his] search" and proclaims, "There isn't a man here that I should be ashamed."

With reference to Spivak's concept on the subaltern, Devi's Dopdi represents the gendered subaltern subject who exists at the periphery of society and dares to go against the existing patriarchal structures. (Spivak) Dopadi, a woman of strong mind filled with courage of conviction, does not break down even after days of continuous gang rape, abuse and hunger. Dopdi subverts the physicality of her body from powerlessness into powerful resistance. Devi's 'Draupadi 'refuses to be emotionally wounded. She confronts the army officers with her bare body, the body that was violated and tortured is reversed to be used as a weapon. With her violated body she faces her abusers with a strong fierce glare and mocking laughter. Refusing to be clothed, she looks into the eyes of Senanayak and questions the very concept of 'shame' for awoman's body in the society where men have objectified women and do not have any respect for her being.

Devi is well known for reinventing the ancient epic and myths, like other post-colonial writers like Girish Karnad in his dramas such as Yayati, Hayavadana, Nagamandala, etc., who sets the mythical characters in the modern perspective with subtle allusions and offers an interpretation of life which integrates past with present and offers an effective and comprehensive view point on a given subject. InDraupadi, the character of Draupadi or Dopadi has circumstantial parallel 
with the mythical character of Draupadi in the epic the Mahabharata where she is depicted as the epitome of the plight of feminine vulnerability subject to ravages by the existing phallocentric society. The 'cheerharan' of Draupadi in the infamous incident where the princess Draupadi is almost disrobed, has been reconstructed in the context of Dopdi's situation. Draupadi of Mahabharata is kept as a price for the dice game where the Padavas, her husbands, lose the game and so Draupadi to the Kauravas.A symbol of Pandavas' honour, the menstruating Draupadi is dragged and brought to the court from her rest room in order to humiliate the Pandavas. The Kauravas attempted to disrobe her as a tool to inflict mortal affront toher husbands. With all the men refusing to intervene in the name of 'Dharma' in spite of Draupadi's pleadings, her feminine identity is defined as weak, helpless and subhuman. Her cry for help is heard by Lord Krishna who protects and saves her 'honour' by stretchingher sari endlessly so as to keep her body covered in front of the court assembly.

In the story Devi's Draupadi does not just 'represent' the subaltern, the politics around the category of the 'subaltern has also been effectively explored. Devi has not allowed her female protagonist, Dopdi, to be submissive and victimized by the patriarchal society in the garb of sanctity and shame for her feminine body. The allusion to the ancient patriarchal Hindu epic through the protagonist's name, Devi lashes out at the traditional social 'ritual' and custom of objectification of female body as honour, dignity and weakness of one's family. Her Dopdi is not saved through any divine intervention, instead she herself takes a defiant posture against the ongoing torture of women through ages. She presents herself naked in front of Senanayak, she wipes the blood from pubic hair and ululates in terrifying voice, "What's the use of clothes? You can strip me, but how can you clothe me again? Are you a man?" Her refusal to clothe back shows her indomitable attitude towards the oppressors, she refuses to be a victim making the men "terribly afraid". Through the relocation of the epic princess Draupadi to the context of tribal rebel Dopdi,

Devi not only questions the objectification of women as a thing which can be cowed down when stripped and sexually assaulted, but gives voice to the subaltern who 'cannot speak'. Devi portrays Dopdi's act of refusal to clothe the nakedness as a weapon of defiance against patriarchal values and the hegemonic social and authoritarian structures personified in the policemen and Officer Senanayek.

Thus, in Draupadi, Devi effectively presents a strong woman who, despite being marginalized and exploited, transgresses conventional sexual and societal standards. Dopdi dares to convert the vulnerable physicality of her body from powerlessness into powerful resistance. Unfortunately, we are still living in a phallocentric and stratified social environment where the voice of protest by the marginalized is ultimately silenced by the powerful forces in the centre. With the biased social and mental conditioning of people's mind, the mainstream believes that a protesting voice is a mere transgression from the trodden path, liable to be punished inhumanly. The story explores the dynamics of injustices by local landed elite, government officials and phallocentric society which is often the cause ofinsurgencies. The abject poverty of the fellow sufferers further worsens the challenging task of raising voice against the oppression by dominant sections of society, who have the direct support of the state-agencies - politicians, the police, and the administration. In the story we find how Dulna and later on Draupadi are betrayed by their own people.Victims of economic injustice, the poverty-stricken members of the community deceive their own leaders, the champions of their own cause. They end up revealing their hideouts and identity for a meagre amount of money. The simple graphic narration powerfully exposes the existence of exploitation and the vicious circle of agrarian tribal community getting into the trap of moneyed class in which hunger and want make people enemy of one's own. Dopdi's body becomes a site of both the exertion of hegemonic 
patriarchal cum authoritarian power and of gendered resistance. India has millions of Dopdi in every corner of the country whom the sensitive Devi has lent them her voice in a very effective manner.

\section{REFERENCES}

1. Arya, Shachi. Tribal Activism: Voices of Protest. Jaipur: Rawat Publications, 1998.

2. Devi, Mahasweta. "The Author in Conversation." Imaginary Maps. Trans. Gayatri Chakravorty Spivak. Calcutta: Thema, 2001 .

3. Al. Wisnubr Oto, B. Hengky Widhi Antoro \& Suryo Adi Pramono, "The Conflict of Interest Between People and Corporation in the Construction Project of Apartment in Yogyakarta Indonesia A Socio-Legal Perspective “, International Journal of Environment, Ecology, Family and Urban Studies (IJEEFUS), Vol. 8, Issue 5, pp. 15-22

4. Devi, Mahasweta. Draupadi. Operation? Bashai Tudu. Trans. Samik Bandyopadhyay and Gayatri Charavorty Spivak, Kolkata: Thema Books, 2016.

5. Hassan Kinyua Omari, "Justice and Human Rights in Islam ", BEST: International Journal of Humanities, Arts, Medicine and Sciences (BEST: IJHAMS), Vol. 4, Issue 2,pp. 285- 292

6. Bhattacharya,Harihar,Partha Sarkar,and Angshuman Kar,editors.The Politics of Social Exclusion in India: Democracy at the Crossroads. New York: Routledge, 2010.

7. Nuhu L. Garba \& Bashir Bukar, "Reforming Technical Vocational Education and Training for Peace and Development in Nigeria “, International Journal of Humanities and Social Sciences (IJHSS), Vol. 4, Issue 2, pp. 63-70

8. Ghatak, Maitreya. Dust on the Road: The Activist Writings of Mahasweta Devi. Calcutta: Seagull Books, 2000.

9. Gupta,Vishesh. “Varga Sangharsha Ki Vichardhara(The ideology of Class Struggle)”.Dainik Jagran, 30 June, 2009.

10. Katyal, Anjum. "The Metamorphosis of 'Rudali'Rudali: From Fiction to Performance. Mahasweta Devi and Usha Ganguli. Trans. Anjum Katyal. Calcutta: Seagull Books, 1997.

11. Azhar Mahmood \& Fatima Zahoor , "Comparison of Socio-Economic Status of Literate and Illiterate Families in Pakistan ", International Journal of Educational Science and Research (IJESR), Vol. 4, Issue 2, pp. 9-14

12. Spivak, Gayatri Chakravorty. Can the Subaltern Speak? Basingstoke: Macmillan, 1988.

\section{NOTES}

Naxalite Movement in West Bengal broke out in the tribal region of Naxalbari in Northern Bengal in May 1967, when a policeman, Sonam Wangdi, aged 46, was killed by armed tribals resisting police combing of the village which resulted into killing of nine tribals, including six women and two children. The local movement grew and spread fast, even getting support of a section of young urban intellectuals besides other assorted elements, which eventually led to the polarization of left oriented political forces in the country. 
